\title{
THE IMPACT OF THE INTERNATIONAL CONSTRUCTION STANDARD APPLICATION CAPABILITY ON CONTRACTORS' COMPETITIVENESS: CHINESE CONTRACTORS' EXPERIENCE
}

\author{
Dingyuan MA ${ }^{1}$, Xiaodong $\mathrm{LI}^{1^{*}}$, Chen $\mathrm{CHENG}^{2}$ \\ ${ }^{1}$ Department of Construction Management, School of Civil Engineering, \\ Tsinghua University, 100084 Beijing, China \\ ${ }^{2}$ China Resources (Holdings) Co., Ltd., 518057 Shenzhen, China
}

Received 2 July 2020; accepted 7 September 2020

\begin{abstract}
The application capability of international construction standards (ICS) has become a necessary element for the success of contractors in the international market. However, there is a lack of quantitative analysis of the impact of ICS application capability on contractors' competitiveness. This paper aims to explore the driving paths between them. The authors divided the competitiveness indicators into market performance indicators and image performance indicators and developed a standard application capability measurement scale based on five dimensions (knowledge learning, talent guarantee, technical support, relationship management and organization guarantee). Then, a structural equation model (SEM), in which project performance was regarded as a mediator variable, was established to investigate the path and intensity of ICS application capability on contractors' competitiveness. A questionnaire was distributed to the project personnel of Chinese contractors engaged in international projects, and 174 valid questionnaires were collected. The results show that 1 ) relationship management and technical support have a direct driving effect on the competitiveness of contractors; 2) talent guarantees and organization guarantees affect contractors' competitiveness through project performance. This study can remind contractors of the importance of the ICS application capability and the weakness of ICS application. Additionally, it will ultimately help contractors adjust their competitiveness strategies.
\end{abstract}

Keywords: international construction standards, application capability, contractors' competitiveness, structural equation modelling, international construction market, international competitiveness.

\section{Introduction}

Recently, the international construction market has received increasing attention, which has given Chinese contractors more opportunities. With the development of the world economy and the acceleration of globalization, the business scope of contractors is expanding globally (Liu et al., 2016). Moreover, relevant policies have been proposed in China to encourage Chinese enterprises to trade in the international market. As the flagship industry mentioned in these policies, contractors play an important role in the international trade of China. Joining the international market is a key step of contractors' development. In addition, 75 Chinese contractors have entered the list of the world's 250 largest international contractors according to the Engineering News-Record [ENR] (2019) magazine, and the business volume of Chinese contractors has ranked first for years. In 2019, China accounted for $60.9 \%$ of the market in Africa, $40.8 \%$ in Asia and 24.3\% in Latin America, which shows that the international construction market is crucial for Chinese contractors.

Nondomestic contractors face severe challenges due to the different technology and institutional environments in the international market (Chang et al., 2018). Unlike the domestic market, the standards involved in international projects are diverse, and the engineering background is relatively complex and cross-cultural (Han \& Diekmann, 2001; Javernick-Will \& Scott, 2010). Eybpoosh et al. (2011) noted that international construction projects are affected not only by project-related factors but also by international market-related factors, such as host government policy and culture risks, resource fluctuations, and different construction standards (Liu et al., 2016). Standards are considered the basis for engineering construction (Yates

${ }^{*}$ Corresponding author. E-mail: eastdawn@tsinghua.edu.cn 
\& Aniftos, 1997). Due to the influence of colonialism and historical factors, the international construction market is dominated by the European and American standard systems, which are quite different from Chinese construction standards in many aspects (Lei et al., 2017). Zhao et al. (2009) concluded that one of the weaknesses of nondomestic contractors entering the international market was that they were not familiar with the local standard system. Likewise, Lei et al. (2017) analyzed the technical standards in the international construction market and noted that Chinese contractors' unfamiliarity with international standards leads to poor project performance, such as cost increases, duration extensions and quality issues. Some research has also found that the ICS application capacity of Chinese contractors does not meet the needs of their increased international contracting business (Yan, 2012). Therefore, how to improve the ICS application capability is a meaningful issue. However, studies on ICS application capability are rarely reported, and its dimensions require further research.

Competition under diverse construction standards is a challenge that Chinese contractors face when entering the international market, but few relevant studies have considered the relationship between ICS application capability and contractors' competitiveness. At present, some studies have addressed the competitiveness of contractors, including competitiveness evaluation models (Han et al., 2015), competitiveness strategy analysis (Yan, 2017), and the impact of environmental activities on international competitiveness (Tan et al., 2015). Deng et al. (2013) utilized the Porter diamond model to analyze the factors influencing the competitiveness of developing countries in the international construction market, including a stable domestic market, supply chain management, enterprise management practice, qualified professionals, satisfactory business environment and labor force. Zhao et al. (2009) conducted a SWOT analysis on the performance of Chinese contractors in the international market, including market environment, contractors' capabilities and resource differences. However, these studies have noted differences between the international market and the domestic market for nondomestic contractors to implement projects. Nevertheless, academic research has paid little attention to issues regarding ICS application capability, let al.ne the driving path of ICS application capability to contractors' competitiveness.

Based on the above analysis, this paper aims to explore the driving paths of ICS application capability on contractors' competitiveness by establishing an SEM with data from questionnaires and expert interviews. This paper is structured as follows: Section 1 reviews the current research on competitiveness and ICS application capability. In Section 2, the research methodology for SEM is presented with hypotheses and data collection. The results of the path analysis and its implications are discussed in Section 3. The conclusions and limitations are illustrated in the final section of this paper.

\section{Literature review}

The concept of the core competitiveness of enterprises was first proposed by Hamel and Prahalad (1990) in Harvard Business Review. They believed that core competitiveness is a kind of organizational accumulated knowledge. Porter (1990) proposed a diamond model and expressed that competitiveness depended on productivity. Afterwards, many studies have been conducted on international competitiveness in the construction industry, focusing on the competitiveness evaluation model and indicators ( $\mathrm{Li}$ et al., 2017; Gunhan \& Arditi, 2005; Han et al., 2015), competitiveness strategy (Yan, 2017) and so on. For example, Russell and Skibniewski (1988) announced that contractors' competitive strength should include qualification, reputation, performance, finance, operation and technology. Merna and Smith (1990) systematically studied the competitiveness of contractors and constructed a series of evaluation methods for competitiveness. A multi-index fuzzy comprehensive evaluation model of international contractors' competitiveness was established by $\mathrm{Li}$ et al. (2004), who analyzed competitiveness from six aspects, namely, market, talent, technology, capital, organization and image. Then, some scholars concentrated on the successful competitiveness strategies of contractors. Specifically, Gunhan and Arditi (2005) found that the advantages of contractors in the international market were reflected in the project success record, project management level, enterprise cooperation, reputation, corporate image, technical advantages, equipment and labor support. Han et al. (2010) noted that successful international contractors increased their turnover by changing regional markets and improved competitiveness by stabilizing revenue structure with diverse products. Additionally, Han et al. (2015) studied international contractors' competitiveness indicators using the McKinsey matrix. The indicators can be divided into two parts: construction industry competitiveness (market risk factors) and construction business strength (technology, finance, image and other factors). Li et al. (2017) considered Chinese contractors and illustrated that market performance can be reflected by five aspects (turnover, quantity and ranking, market share, market region and industry share) based on data from the largest 250 international contractors in the world from 2000 to 2015.

Based on a review of the above literature, the relevant factors of competitiveness can be summarized as follows. However, according to Table 1, only a few scholars have addressed international construction standards. Such standards were mentioned by only few studies as a factor of the institutional environment or market environment but have not been analyzed as a single dimension (Zhao et al., 2009). Due to the different institutional environments in the international market, the importance of international standards should be emphasized. Foreign developed countries have been committed to international and regional standardization for a long time (Komurlu et al., 2015), and their construction standards have strong market recogni- 
Table 1. Contractors' competitiveness index

\begin{tabular}{|c|c|c|c|c|c|c|c|}
\hline \multirow[b]{2}{*}{ Classification } & \multicolumn{7}{|c|}{ Key indicator } \\
\hline & Finance & Technology & Talent & Market & $\begin{array}{l}\text { Relationship } \\
\text { management }\end{array}$ & Image & $\begin{array}{c}\text { Project } \\
\text { management }\end{array}$ \\
\hline Russell and Skibniewski (1988) & $\sqrt{ }$ & $\sqrt{ }$ & & $\sqrt{ }$ & & $\sqrt{ }$ & $\sqrt{ }$ \\
\hline Merna and Smith (1990) & $\sqrt{ }$ & $\sqrt{ }$ & & & & & $\sqrt{ }$ \\
\hline Hatush and Skitmore (1997) & $\sqrt{ }$ & $\sqrt{ }$ & & & & $\sqrt{ }$ & $\sqrt{ }$ \\
\hline Li et al. (2004) & $\sqrt{ }$ & $\sqrt{ }$ & $\sqrt{ }$ & $\sqrt{ }$ & $\sqrt{ }$ & $\sqrt{ }$ & \\
\hline Gunhan and Arditi (2005) & $\sqrt{ }$ & $\sqrt{ }$ & $\sqrt{ }$ & $\sqrt{ }$ & & $\sqrt{ }$ & $\sqrt{ }$ \\
\hline Zhao et al. (2009) & $\sqrt{ }$ & $\sqrt{ }$ & & $\sqrt{ }$ & & $\sqrt{ }$ & $\sqrt{ }$ \\
\hline Deng et al. (2013) & & $\sqrt{ }$ & $\sqrt{ }$ & $\sqrt{ }$ & $\sqrt{ }$ & & $\sqrt{ }$ \\
\hline Han et al. (2015) & $\sqrt{ }$ & $\sqrt{ }$ & $\sqrt{ }$ & $\sqrt{ }$ & & $\sqrt{ }$ & $\sqrt{ }$ \\
\hline Li et al. (2017) & $\sqrt{ }$ & & & $\sqrt{ }$ & & & \\
\hline
\end{tabular}

tion and influence in the international market. The standards in the international construction market are mainly European and American standards, which are quite different from those in China, especially the structure design codes and standards (Kwon \& Kareem, 2013). Moreover, ICS application has a significant impact not only on project performance (Lei et al., 2017) but also on contractors' competitiveness (Yates \& Aniftos, 1996).

Construction standards refer to normative documents that are determined by consensus and the best order in the field (China National Institute of Standardization, 2002). In this study, the ICS refers to nondomestic construction technical standards and regulations adopted in the process of overseas projects. Moreover, few studies have referred the ICS application capability. At present, most of the research on application capability is focused on e-commerce and education (Wu \& Zhong, 2009; Wu et al., 2011). Based on the definition in these fields, ICS application capability in this study refers to the capability of contractors to apply diverse international construction standards by absorbing relevant knowledge and talent, utilizing suitable technologies, and coordinating with the stakeholders of international projects. According to a review of the related research and the definition, the ICS application capability in this paper contains five key elements, knowledge, talent, technology, relationship and organization. The reasons for choosing these elements are detailed below.

Knowledge learning plays a basic role in the development of enterprises. Faced with the changeable internal and external competitive environment, enterprises are required to keep learning to make timely and reasonable adjustments (Hsu \& Fang, 2009; Javernick-Will \& Scott, 2010). Thus, human resources represent necessary capital for enterprises. The ability to attract and maintain talent is the key strategy to the sustainable competitiveness of enterprises (Batarliene et al., 2017). In the field of construction, the good application of international construction standards also requires talent with international vision and experience. In addition, technology is a core competitiveness element of enterprises (Lu et al., 2008). Especially in the construction industry, engineering-related technology is the basis for contractors to engage in engineering projects. For relationship management, there are many participants in construction projects, including owners, contractors, supervisors, materials suppliers, subcontractors, and financial institutions (Rose, 2013). Contractors need to cooperate with other participants in the implementation of projects. In this study, relationship management of international construction standards refers to external collaboration with other participants. In addition, as the enterprise's collaboration includes internal collaboration and external collaboration, internal collaboration has almost the same meaning as the organization guarantee referred to in this study. It is believed that internal management and control could improve the efficiency and effectiveness of the organization (Mahadeen et al., 2016). Theoretically, the improvement of organization guarantees is conducive to a better understanding and use of international construction standards. Thus, international standard knowledge learning (KL) (Hsu \& Fang, 2009), talent guarantee (TG) (Wright \& McMahan, 1992), technical support (TS) (Ogwueleka, 2011), relationship management (RM) (Ansoff \& McDonnell, 1988) and organization guarantee (OG) (Anthony, 1988) are applied as dimensions of ICS application capability in this study.

Competition with foreign standards is unavoidable for nondomestic contractors when entering the international market. Some relevant studies have recognized the important impact of international construction standards on project performance and enterprise development. Lei et al. (2017) noted that international construction technology standards affect project performance. Likewise, Gao (2010) proposed a series of methods from the perspective of contractors to strengthen the application of domestic quota standards in bidding, which can enhance the competitiveness of contractors. Regarding the application of ICS, few studies have conducted qualitative analyses. Turk (2006) conducted interviews on ISO 9000 use in construction firms from the perspective of developing countries and summarized the difficulties and disadvantages of 
ISO 9000 QMS application. Yan (2012) analyzed the reasons for the formation of construction standards in international projects and proposed suggestions to improve the application capability of ICS, including improving the corresponding construction technology level, performing a comparative study of construction standards at home and abroad, personnel training and construction. The above research has analyzed the difficulties and reasons of the ICS application capability by interviews and proposed suggestions. However, there is a gap that few studies have quantitatively analyzed the casual link between the ICS application capability and international contractors' competitiveness. Thus, this paper aims to explore the relationship between them by quantitative analysis.

\section{Methodology}

\subsection{Theoretical analysis and hypotheses}

\subsubsection{Theoretical basis}

Structural equation modeling (SEM) is a multivariable statistical technique that can make unobservable latent variables more specific (Cheung \& Chow, 2011).It is a method based on theoretical and practical experience and widely used in the construction industry (Durdyev et al., 2018; Gunduz et al., 2017). According to interviews and practical experience with projects, during the implementation of international projects, many problems in cost, construction period and quality arise because of the lack of familiarity with international construction standards (Lei et al., 2017). The application of international construction standards, especially technical standards, plays a direct role in promoting project performance. In addition, some scholars have noted that the Chinese international construction community has formed a consensus on the application capability of international construction standards: the ICS application capability of Chinese international contractors cannot meet the needs of the development of international contracting business (Yan, 2012). Therefore, an improvement in ICS application capability could promote the development of international contracting business and enhance the competitiveness of contractors. Additionally, based on a literature review, international project performance is applied as the mediator variable in the SEM. Thus, the initial theoretical framework is shown in Figure 1. In the model, KL, TG, TS, RM and OG are five dimensions of the ICS application capability, and they are set in the context of international construction standards. Besides, market performance and image performance are two indicators that indicates contractors' competitiveness in international construction market. The hypotheses referred to in Figure 1 are explained below in detail.

\subsubsection{ICS application capabilities and contractors' competitiveness}

Knowledge learning $(\mathrm{KL})$ can be divided into knowledge stock and learning flow. Knowledge stock refers to the learning and storage of knowledge at the individual level, team level and organization level, and learning flow involves knowledge sharing and knowledge development. Many studies have confirmed the positive effect of knowledge learning on competitiveness. Research by Prieto and Revilla (2006) indicated that learning capability was conducive to the financial performance and nonfinancial performance of enterprises, which can be regarded as market performance and image performance, respectively. This conclusion has been verified by Mohamad and Zin (2019). Moreover, good knowledge management and strong innovation could have a positive impact on the competitiveness of small contractors. Thus, the following hypotheses are proposed:

H1: Knowledge learning (KL) positively influences the market performance of competitiveness (CP-M).

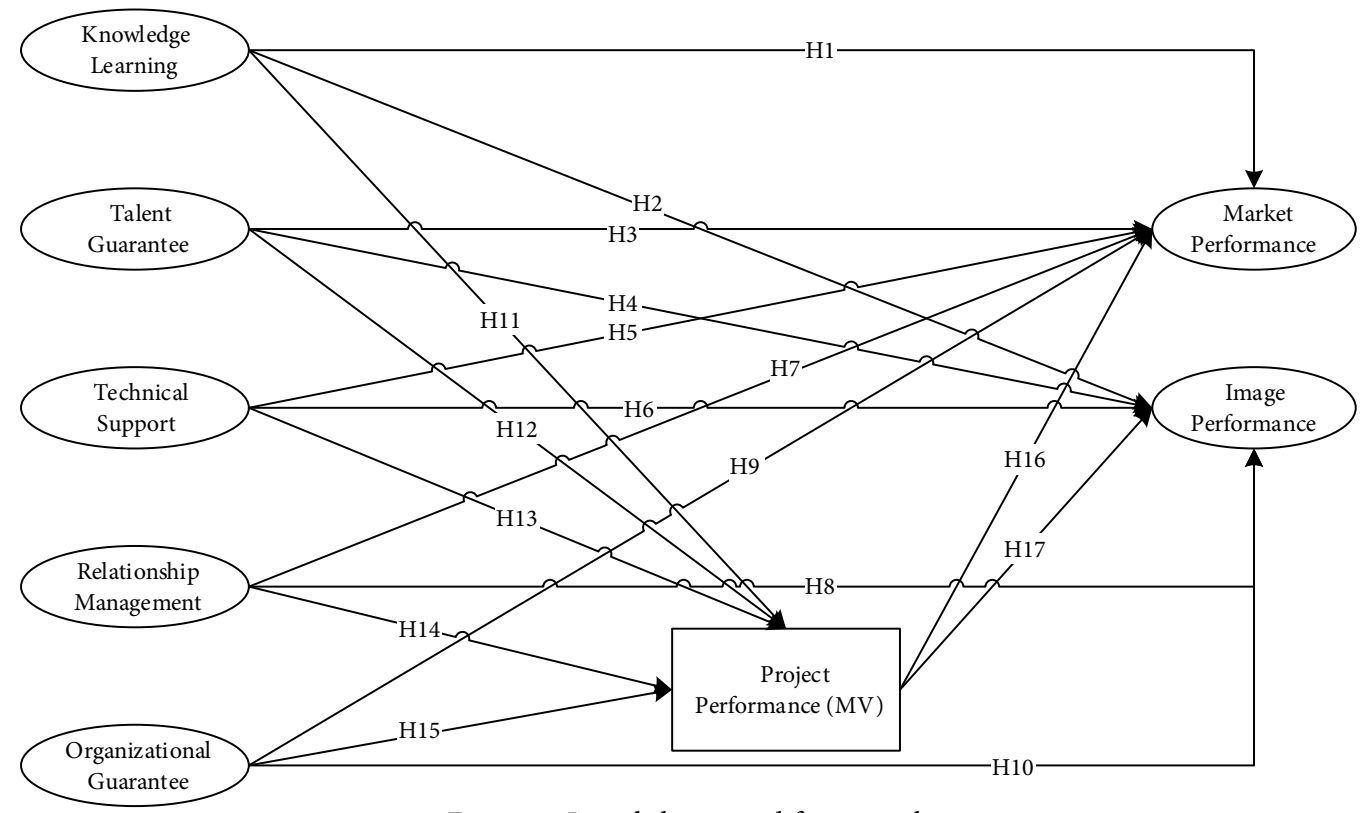

Figure 1. Initial theoretical framework 
$\mathrm{H} 2$ : Knowledge learning (KL) positively influences the image performance of competitiveness (CP-I).

Regarding talent guarantees, most studies have found that human resource management is one of the most effective competitiveness strategies for enterprises (Khandekar \& Sharma, 2005). Wright and McMahan (1992) found that the attitude and behavior of employees and the organizational performance of enterprises can be improved through human resource management. Likewise, Matlay et al. (2005) believed that human resources are a critical factor for the sustainable competitiveness of enterprises. Ogunyomi and Bruning (2016) investigated enterprises in developing countries using multiple regression and found that certain HRM practices can promote enterprise performance. Therefore, the following hypotheses are proposed:

H3: Talent guarantees (TGs) positively influence the market performance of competitiveness (CP-M).

H4: Talent guarantees (TGs) positively influence the image performance of competitiveness (CP-I).

When considering the implementation of a project, it is widely agreed that technology is the basis. Pheng and Hongbin (2003) analyzed the development of the top 225 contractors in ENR and found that the low R\&D investment of Chinese contractors places them in a vulnerable position compared with contractors in developed countries such as Europe and the United States. Similarly, technology, which can help contractors obtain advantages of competitiveness, was recognized as a critical success factor in the international construction market. Thus, the following hypotheses are proposed:

H5: Technical support (TS) positively influences the market performance of competitiveness (CP-M).

H6: Technical support (TS) positively influences the image performance of competitiveness (CP-I).

It is widely recognized that better communication and relationships among stakeholders will help the development of enterprises (Hooley et al., 2005; Paulraj et al., 2008). Relationship management in this study refers to the good cooperation and communication of contractors with respect to the application of the ICS with the subcontractor, the owner, the supervisor and the supply chain enterprise. Hooley et al. (2005) defined customer relationship management (CRM) as a kind of market-oriented resource that plays a positive role in promoting customer satisfaction and the market performance of enterprises. In addition, many scholars have focused on the relationships among contractors and stakeholders in projects. Paulraj et al. (2008) emphasized the positive influence of good external communication on the cooperation of contractors and owners. It is believed that excellent CRM can help enterprises gain market-oriented advantages in competition, and conversion feasibility can be used to make adjustments in this process. In addition, Tan et al. (2017) noted the importance of relationships among subcontractors and contractors and conducted questionnaires in Hong Kong. A good relationship with subcontractors is positively and advantageously associated with contractors' competitiveness. Thus, the following hypotheses are proposed:

H7: Relationship management (RM) positively influences the market performance of competitiveness (CP-M).

H8: Relationship management (RM) positively influences the image performance of competitiveness (CP-I).

Many previous studies have investigated the relationship between competitiveness and organizational factors (such as organizational culture, internal control and organizational performance). Kotter and Heskitt (1992) found that organizational culture has a significant promotion effect on organizational performance by investigating 72 companies in 22 industries in the United States. Additionally, organizational culture can be used to distinguish different levels of competitiveness (Galetić et al., 2012). Mahadeen et al. (2016) found that the internal control system had a significant impact on organizational effectiveness. Thus, the following hypotheses are proposed:

H9: Organization guarantees (OGs) positively influence the market performance of competitiveness (CP-M).

H10: Organization guarantees (OGs) positively influence the image performance of competitiveness (CP-I).

\subsubsection{ICS application capabilities and project performance}

Some research has studied the impact of knowledge management on project performance, and the importance of knowledge learning has been confirmed (Adenfelt, 2010; $\mathrm{Ng}$ et al., 2011). Specifically, Adenfelt (2010) discussed the relationship between knowledge sharing and transnational project performance. An empirical data analysis of questionnaires showed that knowledge sharing, especially tacit knowledge sharing, can significantly improve project performance. Accordingly, the following hypothesis is proposed:

H11: Knowledge learning (KL) positively influences project performance (MV).

The positive effect of talent on project performance has been identified by many scholars (Gurmu, 2020; Yu et al., 2006). Gurmu (2020) noted that suitable human resource management (HRM) practices can enhance labor productivity by using a fuzzy synthetic evaluation approach. Abuazoom et al. (2019) quantitatively analyzed the importance of HRM to project quality performance with questionnaires from the top managers of contractors. Thus, the following hypothesis is proposed:

H12: Talent guarantee (TG) positively influences project performance (MV).

Many studies have analyzed the success factors influencing project performance, and technical factors have been mentioned. Ogwueleka (2011) studied the success factors influencing project performance in Nigeria and 
found that technical factors were among the key elements for successful project performance. Moreover, project management maturity is related to technical support (Berssaneti \& Carvalho, 2015). Thus, the following hypothesis is proposed:

H13: Technical support (TS) positively influences project performance (MV).

Relationship management has been emphasized by many scholars in research on project performance. For example, Meng (2012) addressed the impact of supply chain relationship management on project performance. Relationship management has also been regarded as a kind of critical factor in public private projects (Zou et al., 2014). Therefore, the following hypothesis is proposed:

H14: Relationship management (RM) positively influences project performance (MV).

Regarding organization guarantees, Moon (2010) studied organizational cultural intelligence from a dynamic perspective and defined organizational cultural intelligence as a kind of cultural adaptability, that is, the capability of an organization to be competitive in a multicultural environment. It is believed that organizational cultural intelligence has a positive impact on organizational performance in some aspects, such as financial performance, internal operations, learning, growth, and customer satisfaction. Thus, the following hypothesis is proposed:

H15: Organization guarantees (OGs) positively influence project performance (MV).

\subsubsection{Project performance and contractors' competitiveness}

Project-oriented enterprises are defined as enterprises that complete various activities for a project, and each project is accounted for as an independent production unit (Lindkvist, 2004). Bassioni et al. (2005) proposed a conceptual model to measure contractors' performance through a series of expert interviews and case studies and identified the driving effect of project performance on contractors' competitiveness. Elyamany (2010) supports the view that past project performance, including the overall success of the project, progress performance, quality performance, safety record, number of completed projects and delivery history, is one selection criterion for contractors. These arguments lead to the following hypotheses:

H16: Project performance (MV) positively influences the market performance of competitiveness (CP-M).

H17: Project performance (MV) positively influences the image performance of competitiveness (CP-I).

The above 17 hypotheses constitute the initial theoretical framework presented in Figure 1, where arrows illustrate the direction of the hypothesized influences.

\subsection{Measures}

Based on a literature review and expert interviews, a 37 -item initial scale was developed. The definitions and relevant items of each dimension are elaborated in detail below.

\subsubsection{Contractors' competitiveness}

According to the influencing factors and forms of competitiveness mentioned in the previous literature (Deng et al., 2013; Han et al., 2015; Zhao et al., 2009), competitiveness in this paper refers to turnover, market sharing, corporate image, etc. Additionally, the international contractors' competitiveness was divided into two parts according to the above studies (Gunhan \& Arditi, 2005; Han et al., 2010) and expert interviews: market performance and image performance. Therefore, competitiveness was measured by 10 items ( 5 for market performance and 5 for image performance).

\subsubsection{Knowledge learning}

In this study, the measurement variables of knowledge learning refer to the relatively mature research results of organizational learning. As early as 1997, Goh and Richards proposed five characteristics of organizational learning, namely, clear goals and vision, leadership commitment and authorization, exploration and innovation, and incentives, knowledge sharing and team work (Goh \& Richards, 1997). Afterwards, many relevant studies have examined the dimension of organizational learning. Jerez-Gómez et al. (2005) believed that organizational learning includes four dimensions: management commitment, system thinking, openness and experimentation, and knowledge transfer and integration. Marsick and Watkins (2003) divided organizational learning into three levels: individual level, team level and organization level. Specifically, 7 dimensions were considered (continuous learning, inquiry, communication, team cooperation, team learning, building learning system, strategic leadership, awareness of organization members, and internal and external collaborative learning). Based on the above seven dimensions, the Dimensions of Learning Organization Questionnaire (DLOQ) was developed. The questionnaire has detailed description items for each dimension and has been recognized in many studies (Chai \& Dirani, 2018; Marsick, 2013). According to the DLOQ and the characteristics of the construction project, the dimensions of ICS knowledge learning in this study cover individual learning, leadership learning, knowledge reservation, knowledge sharing, and related resource input.

\subsubsection{Talent guarantee}

Talent guarantees are based on good human resource management. Human resource management can ensure that the talents of enterprises fulfill their work better and bring competitive advantages (Ogunyomi \& Bruning, 2016). Armstrong and Taylor (2014) noted that HRM includes planning and recruitment, selection and induction, performance management, learning and development and recognition and reward. This issue has also been discussed by recent research. Hasan et al. (2019) proposed a contemporary HRM framework that discussed the key elements 
of HRM, including recruitment, selection, performance appraisal, training and development. In the construction industry, Shahhosseini and Sebt (2011) conducted a study on the selection and distribution of human resources and divided engineering personnel into project managers, engineers, technicians and construction workers. The indices include three aspects: technology, behavior and situation handling. Based on the above literature results, three components are considered in this study: technology, behavior and situation processing.

\subsubsection{Technical guarantee}

The technical guarantee of enterprises is crucial for them to adapt to a changeable and unpredictable environment and enhance competitiveness. Therefore, technical guarantees include not only the static strategic elements of technology itself but also the dynamic resource reconstruction of technology transformation and creation. Sharif (1997) believed that the technical structure of enterprises included four aspects: production tools and equipment, production technology and experience, information technology and production arrangement and organization. Likewise, Archibugi and Coco (2004) investigated the dimensions of the technical structure and divided it into three aspects: technology foundation, technology creation and the development of skilled talent. In the field of construction, recent studies on the technology management of contractors have focused on the application of information technology. Erdogan et al. (2010) noted that by 2030, information technology would reshape the future of the construction industry. Iliescu and Ciocan (2017) found that the use of modern innovative technologies such as GPS monitoring, visualization technology and RFID technology to manage engineering projects can improve quality and safety, reduce losses and bring profits to enterprises. Furthermore, the application of RFID in construction engineering could make safety control systems more accurate and efficient and make the project life cycles simple and automatic (Valero \& Adán, 2016).

Thus, 6 items of technical support (advancement of technology, technical research and development, technical data management, technology monitoring, modern technology) were considered.

\subsubsection{Relationship management}

Contractors are required to coordinate and cooperate with many participants in the implementation of a project. In this study, relationship management means external coordination of contractors with other stakeholders. Thus, studies on external coordination can serve as a reference. Foster-Fishman et al. (2001) noted that relationship management could be established through sharing, respect, positive external relations and working atmosphere. Meanwhile, van Popering-Verkerk and van Buuren (2017) defined external coordination as coordination ability at the network level, which refers to constructive dialogue and mutual adaptation with participants and the establish- ment of a cooperative relationship based on mutual trust and understanding. The key indicators of supply chain relationships in construction were also considered by Meng (2012), including mutual objectives, sharing, trust, no-blame culture, joint working, communication, problem solving, risk allocation, performance measurement, and continuous improvement. Based on the research results on the external coordination of enterprises above, the content question setting of the relationship management of ICS application capability in this study focuses on cooperation with owners, subcontractors, supervisors and supply chain enterprises.

\subsubsection{Organization guarantee}

In contrast to external relationship management, organization guarantees in this study can be regarded as internal collaboration. Anthony (1988) defined that management control as the process by which managers achieve organizational development objectives by influencing other members of the organization. This is a mainstream concept in management control research. The Committee of Sponsoring Organizations of the Treadway Commission [COSO] (2019) published a document about the overall framework of internal control that defines internal control as a work process for an organization to reasonably ensure their objectives. According to the document, internal control is implemented by the board of directors, management authorities and other relevant employees for the purpose of increasing operating efficiency, obtaining reliable financial reports and ensuring compliance with laws and regulations. Therefore, internal control is a guarantee for the realization of organizational goals. Norris and O'Dwyer (2004) believed that the management control system included two parts: formal control and informal control. Ferreira and Otley (2009) divided the management control system into 12 parts: vision and mission, key success factors, organizational structure, strategy and planning, key performance measures, goal setting, performance evaluation, etc. Similarly, Lueg and Radlach (2016) investigated the enterprise management control system and divided it into cultural control, plan control, control evaluation, reward and compensation, organizational structure and other administrative control. Thus, from the perspective of project organization, the items of organization guarantee in this paper cover internal communication mechanisms, cultural awareness, organizational structure and management systems.

Due to the absence of existing suitable scales for this study to apply directly, numerous studies were reviewed, and expert interviews were conducted. In the end, 37 items of measurement ( 6 for knowledge learning, 6 for talent guarantee, 6 for technology support, 3 for relationship management, 6 for organization guarantee, 10 for competitiveness) were identified, as shown in Table 2. A five-point Likert scale ( 1 - very bad; 3 - medium; 5 -very good) was applied. 
Table 2. Summary of items

\begin{tabular}{|c|c|c|c|}
\hline \multicolumn{2}{|c|}{ Latent variables } & Items & Reference \\
\hline \multirow{6}{*}{$\begin{array}{l}\text { Knowledge } \\
\text { learning }\end{array}$} & KL1 & $\begin{array}{l}\text { Comparative study and application experience summary of } \\
\text { ICS }\end{array}$ & $\begin{array}{l}\text { Goh and Richards (1997); Marsick and } \\
\text { Watkins (2003) }\end{array}$ \\
\hline & KL2 & Knowledge and experience sharing of ICS application & $\begin{array}{l}\text { Goh and Richards (1997); Jerez-Gómez et al. } \\
\text { (2005) }\end{array}$ \\
\hline & KL3 & Effective system training in advance & Jerez-Gómez et al. (2005) \\
\hline & KL4 & $\begin{array}{l}\text { Sufficient communication and shared resource platform } \\
\text { provided }\end{array}$ & Marsick and Watkins (2003) \\
\hline & KL5 & $\begin{array}{l}\text { Guidance from project managers to subordinate project } \\
\text { members }\end{array}$ & Goh and Richards (1997) \\
\hline & KL6 & Storage of materials and standard translation versions of ICS & Jerez-Gómez et al. (2005) \\
\hline \multirow{6}{*}{$\begin{array}{l}\text { Talent } \\
\text { guarantee }\end{array}$} & TG1 & Employment of project personnel with professional knowledge & Shahhosseini and Sebt (2011) \\
\hline & TG2 & Project managers with rich experience & Shahhosseini and Sebt (2011) \\
\hline & TG3 & $\begin{array}{l}\text { Technical personnel/workers with professional knowledge and } \\
\text { skills }\end{array}$ & Shahhosseini and Sebt (2011) \\
\hline & TG4 & Incentives for project personnel & Shahhosseini and Sebt (2011) \\
\hline & TG5 & Knowledge sharing of local project personnel (e.g., engineers) & $\begin{array}{l}\text { Marsick and Watkins (2003); Shahhosseini } \\
\text { and Sebt (2011) }\end{array}$ \\
\hline & TG6 & Training and reserve of related translators & Shahhosseini and Sebt (2011) \\
\hline \multirow{6}{*}{$\begin{array}{l}\text { Technical } \\
\text { support }\end{array}$} & TS1 & Materials and equipment in accordance with ICS & Sharif (1997); Zahra et al. (2007) \\
\hline & TS2 & Investment in construction technology innovation & Zahra et al. (2007) \\
\hline & TS3 & Recording, arrangement and preservation of relevant data & Sharif (1997) \\
\hline & TS4 & Effective technology-related research in advance & $\begin{array}{l}\text { Archibugi and Coco (2004); Zahra et al. } \\
\text { (2007) }\end{array}$ \\
\hline & TS5 & Technology preparation and implementation plan & Sharif (1997); Archibugi and Coco (2004) \\
\hline & TS6 & Information technology support & $\begin{array}{l}\text { Erdogan et al. (2010); Iliescu and Ciocan } \\
\text { (2017) }\end{array}$ \\
\hline \multirow{3}{*}{$\begin{array}{l}\text { Relation- } \\
\text { ship man- } \\
\text { agement }\end{array}$} & RM1 & $\begin{array}{l}\text { Effective negotiation, communication and cooperation with } \\
\text { the owner }\end{array}$ & van Popering-Verkerk and van Buuren (2017) \\
\hline & RM2 & $\begin{array}{l}\text { Effective communication and cooperation relationship with } \\
\text { the supervisor }\end{array}$ & van Popering-Verkerk and van Buuren (2017) \\
\hline & RM3 & $\begin{array}{l}\text { Effective cooperation with subcontractors, suppliers and } \\
\text { designers }\end{array}$ & van Popering-Verkerk and van Buuren (2017) \\
\hline \multirow{6}{*}{$\begin{array}{l}\text { Organiza- } \\
\text { tion guar- } \\
\text { antee }\end{array}$} & OG1 & Effective communication mechanism within the enterprise & COSO (2019) \\
\hline & OG2 & Cooperation with the local organization & $\begin{array}{l}\text { Ferreira and Otley (2009); Lueg and Radlach } \\
\text { (2016) }\end{array}$ \\
\hline & OG3 & Attention of managers to the application of ICS & Ferreira and Otley (2009) \\
\hline & OG4 & Cultural awareness & $\begin{array}{l}\text { Ferreira and Otley (2009); Norris and } \\
\text { O’Dwyer (2004) }\end{array}$ \\
\hline & OG5 & Adaptation and adjustment of project organization structure & COSO (2019); Ferreira and Otley (2009) \\
\hline & OG6 & $\begin{array}{l}\text { Adaptation and adjustment of project management system and } \\
\text { specification }\end{array}$ & Ferreira and Otley (2009) \\
\hline \multirow{5}{*}{$\begin{array}{l}\text { Market } \\
\text { perfor- } \\
\text { mance of } \\
\text { competi- } \\
\text { tiveness }\end{array}$} & $\mathrm{CP} 1$ & High bid winning rate & Interview with experts \\
\hline & $\mathrm{CP} 2$ & Realization of project value & Li et al. (2004); Interview with experts \\
\hline & CP3 & High turnover and turnover growth rate & ENR (2019); Han et al. (2010) \\
\hline & $\mathrm{CP} 4$ & High market share & Han et al. (2010) \\
\hline & CP5 & Diversified business areas and regional market & Han et al. (2010) \\
\hline \multirow{5}{*}{$\begin{array}{l}\text { Image per- } \\
\text { formance } \\
\text { of compet- } \\
\text { itiveness }\end{array}$} & CP6 & Owner satisfaction & Gunhan and Arditi (2005) \\
\hline & $\mathrm{CP} 7$ & Good reputation and image & Gunhan and Arditi (2005) \\
\hline & CP8 & Good quality and operation effect & Gunhan and Arditi (2005) \\
\hline & CP9 & High level of leadership & Li et al. (2004); Gunhan and Arditi (2005) \\
\hline & CP10 & Effective avoidance of technical risks & Li et al. (2004); Interview with experts \\
\hline
\end{tabular}




\subsection{Questionnaire survey}

The respondents of this study are all construction managers of large domestic contractors with overseas engineering experience. To eliminate the time difference and geographical restrictions, the questionnaires were distributed as electronic questionnaires. The electronic questionnaire platform also accelerates the return of the questionnaires. Making full use of alumni resources and enterprise visits, 196 questionnaires were collected, of which 174 were valid, with an effective rate of $88.78 \%$, which satisfies the sample requirements of structural equation model data fitting analysis (Bollen, 1989; Nicolaou \& Masoner, 2013).

The demographic distribution of the sample data is shown in Table 3. Of the respondents, $6.32 \%$ have been in overseas projects for less than 1 year, $28.74 \%$ for $1-3$ years, $15.52 \%$ for $3-5$ years, $29.89 \%$ for $5-10$ years, and $19.54 \%$ for more than 10 years. Concerning respondents' positions, approximately $60 \%$ are senior engineers and intermediate engineers. In addition, the effective samples of this study come from different regions and different types of projects, which ensure the representativeness of the sample.

Table 3 Demographic distribution of the sample data

\begin{tabular}{|c|c|c|}
\hline Characteristics & Category & $\%$ \\
\hline \multirow[t]{4}{*}{ Working position } & General staff & $30.46 \%$ \\
\hline & Junior manager & $37.36 \%$ \\
\hline & Intermediate manager & $20.11 \%$ \\
\hline & Senior (project manager) & $12.07 \%$ \\
\hline \multirow[t]{5}{*}{ Professional title } & Professor of engineering & $2.30 \%$ \\
\hline & Senior engineer & $24.14 \%$ \\
\hline & \begin{tabular}{|l|} 
Engineer \\
\end{tabular} & $35.63 \%$ \\
\hline & Assistant engineer & $26.44 \%$ \\
\hline & Other & $11.49 \%$ \\
\hline \multirow{5}{*}{$\begin{array}{l}\text { Working years } \\
\text { for international } \\
\text { projects }\end{array}$} & $\mathrm{Y} \leq 1$ year & $6.32 \%$ \\
\hline & 1 year $<\mathrm{Y} \leq 3$ years & $28.74 \%$ \\
\hline & 3 year $<\mathrm{Y} \leq 5$ years & $15.52 \%$ \\
\hline & 5 year $<\mathrm{Y} \leq 10$ years & $29.89 \%$ \\
\hline & $\mathrm{Y}>10$ years & $19.54 \%$ \\
\hline \multirow[t]{2}{*}{ Region } & Oversea & $49.43 \%$ \\
\hline & Home & $50.57 \%$ \\
\hline \multirow[t]{5}{*}{ Type of project } & Residential Buildings & $33.99 \%$ \\
\hline & Public buildings & $32.01 \%$ \\
\hline & Industrial buildings & $8.91 \%$ \\
\hline & Infrastructure & $24.09 \%$ \\
\hline & Other & $0.99 \%$ \\
\hline \multirow[t]{6}{*}{ Project location } & Europe & $4.17 \%$ \\
\hline & Middle east & $20.08 \%$ \\
\hline & Africa & $40.91 \%$ \\
\hline & North America & $2.27 \%$ \\
\hline & $\begin{array}{l}\text { Latin America and the } \\
\text { Caribbean }\end{array}$ & $6.06 \%$ \\
\hline & Asia and Oceania & $26.52 \%$ \\
\hline
\end{tabular}

\section{Results and analysis}

\subsection{Factor analysis}

\subsubsection{Exploratory factor analysis} for the initial competitiveness scale

Exploratory factor analysis (EFA) was implemented using SPSS 22.0. In addition, principal component analysis (varimax rotation) was conducted. This method has some basic requirements. First, each structural dimension must have three or more measurement items (Floyd \& Widaman, 1995), so TG4 and TG5 were deleted. Then, the factor load of each item in the dimensions of the structural equation model must be more than 0.45 (Price et al., 1993). Additionally, the structural equation model must conform to the theoretical basis and the results, so $\mathrm{CP} 2$ and CP5 were eliminated. The composition of the final formal scale is shown in Table 2.

Cronbach's alpha was used to test the reliability of the hypothesized construct based on the data. Cronbach's alpha can be calculated using SPSS. If the $\alpha$ coefficient does not exceed 0.6 , the internal consistency reliability is generally considered to be insufficient (David, 2003). The Cronbach's alpha of all the observed variables in this study is 0.933 , which indicates good internal consistency and reliability. As shown in the last column of Table 4, all the Cronbach's alpha values of the constructs reached an acceptable level.

\subsubsection{Confirmatory factor analysis for the hypothetical model}

In this study, confirmatory factor analysis (CFA) was conducted to analyze the structure of the formal model, and AMOS software was employed in this process.

Based on previous literature, the evaluation criteria are shown in the third column of Table 5. Thus, the model $\left(\chi^{2} / d F=1.484, G F I=0.807, R M S E A=0.05, I F I=0.896\right.$, $C F I=0.893, T L I=0.881, A G F I=0.771, P G F I=0.682)$ must be corrected. The sum of M.I. (modification indices) calculated by AMOS is used as the basis for modification. First, the items with standardized regression weights $(\beta)$ less than 0.5 (KL1 and KL2), which indicated that the items had little influence on the latent variable, were deleted. Then, according to the M.I. values obtained with AMOS software, the model was corrected many times, and five items (TS2, OG1, OG3, CP7 and CP10) were deleted.

Finally, the overall model with 31 indicators and 7 latent variables reached an acceptable level of fitness $\left(\chi^{2} / d F=1.199, G F I=0.873, R M S E A=0.034, I F I=0.964\right.$, $C F I=0.962, T L I=0.956, A G F I=0.840, P G F I=0.692$ ) and the structural equation model could be constructed.

\subsubsection{Structural equation model}

According to the CFA, the correlation coefficients among KL, TG and TS are all approximately 0.7 , and the correlation coefficient between RM and OG is 0.65 . Therefore, these significant positive covariance relationships are added to the structural equation model, as shown in Figure 2. 
Table 4. Factor loading and Cronbach's alpha of latent variables

\begin{tabular}{|c|c|c|c|c|}
\hline \multicolumn{2}{|c|}{ Latent variables } & Items & Factor loading & Cronbach's alpha \\
\hline \multirow{6}{*}{$\mathrm{KL}$} & KL1 & Comparative study and application experience summary of ICS & 0.649 & \multirow{6}{*}{0.768} \\
\hline & KL2 & Knowledge and experience sharing of ICS application & 0.642 & \\
\hline & KL3 & Effective system training in advance & 0.633 & \\
\hline & KL4 & Sufficient communication and shared resources platform provided & 0.600 & \\
\hline & KL5 & Guidance from project managers to subordinate project members & 0.556 & \\
\hline & KL6 & Storage of materials and standard translation versions of ICS & 0.557 & \\
\hline \multirow{4}{*}{ TG } & TG1 & Employment of project personnel with professional knowledge & 0.730 & \multirow{4}{*}{0.641} \\
\hline & TG2 & Project managers with rich experience & 0.656 & \\
\hline & TG3 & Technical personnel / workers with professional knowledge and skills & 0.566 & \\
\hline & TG6 & Training and reserve of related translators & 0.477 & \\
\hline \multirow{6}{*}{ TS } & TS1 & Materials and equipment in accordance with ICS & 0.729 & \multirow{6}{*}{0.811} \\
\hline & TS2 & Investment in construction technology innovation & 0.627 & \\
\hline & TS3 & Recording, arrangement and preservation of relevant data & 0.572 & \\
\hline & TS4 & Effective technology-related research in advance & 0.484 & \\
\hline & TS5 & Technology preparation and implementation plan & 0.662 & \\
\hline & TS6 & Information technology support & 0.492 & \\
\hline \multirow{3}{*}{$\mathrm{RM}$} & RM1 & Effective negotiation, communication and cooperation with the owner & 0.678 & \multirow{3}{*}{0.738} \\
\hline & RM2 & Effective communication and cooperation relationship with the supervisor & 0.734 & \\
\hline & RM3 & Effective cooperation with subcontractors, suppliers and designers & 0.554 & \\
\hline \multirow{6}{*}{ OG } & OG1 & Effective communication mechanism within the enterprise & 0.602 & \multirow{6}{*}{0.864} \\
\hline & OG2 & Cooperation with the local organization & 0.733 & \\
\hline & OG3 & Attention of managers to the application of ICS & 0.678 & \\
\hline & OG4 & Cultural awareness & 0.683 & \\
\hline & OG5 & Adaptation and adjustment of project organization structure & 0.725 & \\
\hline & OG6 & Adaptation and adjustment of project management system and specification & 0.694 & \\
\hline \multirow{8}{*}{$\mathrm{CP}$} & CP1 & High bid winning rate & 0.770 & \multirow{3}{*}{0.734} \\
\hline & $\mathrm{CP} 3$ & High turnover and turnover growth rate & 0.772 & \\
\hline & $\mathrm{CP} 4$ & High market share & 0.795 & \\
\hline & CP6 & Owner satisfaction & 0.713 & \multirow{5}{*}{0.793} \\
\hline & CP7 & Good reputation and image & 0.712 & \\
\hline & CP8 & Good quality and operation effect & 0.822 & \\
\hline & CP9 & High level of leadership & 0.691 & \\
\hline & CP10 & Effective avoidance of technical risks & 0.622 & \\
\hline
\end{tabular}

Table 5. Results of goodness of fit (GOF) criteria

\begin{tabular}{|c|c|c|c|c|}
\hline GOF measure & Fit index & Evaluation criteria & Baseline model & Final model \\
\hline Chi-square test & $\chi^{2} / d F$ & Smaller than 2 (Marsh \& Hau, 1996) & 1.665 & 1.602 \\
\hline \multirow{3}{*}{ Absolute fit indices } & GFI & Greater than 0.90 (Marsh \& Hau, 1996) & 0.841 & 0.867 \\
\hline & RMSEA & Smaller than 0.08 (Marsh \& Hau, 1996) & 0.062 & 0.059 \\
\hline & $A G F I$ & Greater than $0.80($ Gefen, 2000) & 0.802 & 0.828 \\
\hline \multirow{3}{*}{ Incremental fit indices } & $I F I$ & Greater than 0.90 (Marsh \& Hau, 1996) & 0.879 & 0.902 \\
\hline & CFI & Greater than 0.90 (Marsh \& Hau, 1996) & 0.876 & 0.900 \\
\hline & $T L I$ & Greater than 0.90 (Hair et al., 2009) & 0.856 & 0.878 \\
\hline Parsimonious fit & PGFI & Greater than 0.50 (Ozorhon et al., 2008) & 0.676 & 0.670 \\
\hline
\end{tabular}


The goodness of fit of the baseline model is shown in the fourth column of Table 5 .

The M.I. value obtained by AMOS software was also used for adjustment (from large to small), and TG3, TS4 and RM3 were deleted. In the final model, the only "Relationship Management" items remaining are RM1 and $\mathrm{RM} 2$, but there is a causal and covariant relationship be- tween items of the model, which can be acceptable (McDonald \& Roderick, 1999). Additionally, when $C F I \geq 0.9$, the GFI of the model is reduced to 0.85 (Yao et al., 2013). Thus, as shown in the fifth column of Table 5, the final model was a 'good model'. The standardized path coefficient obtained from the final model is shown in Figure 3.

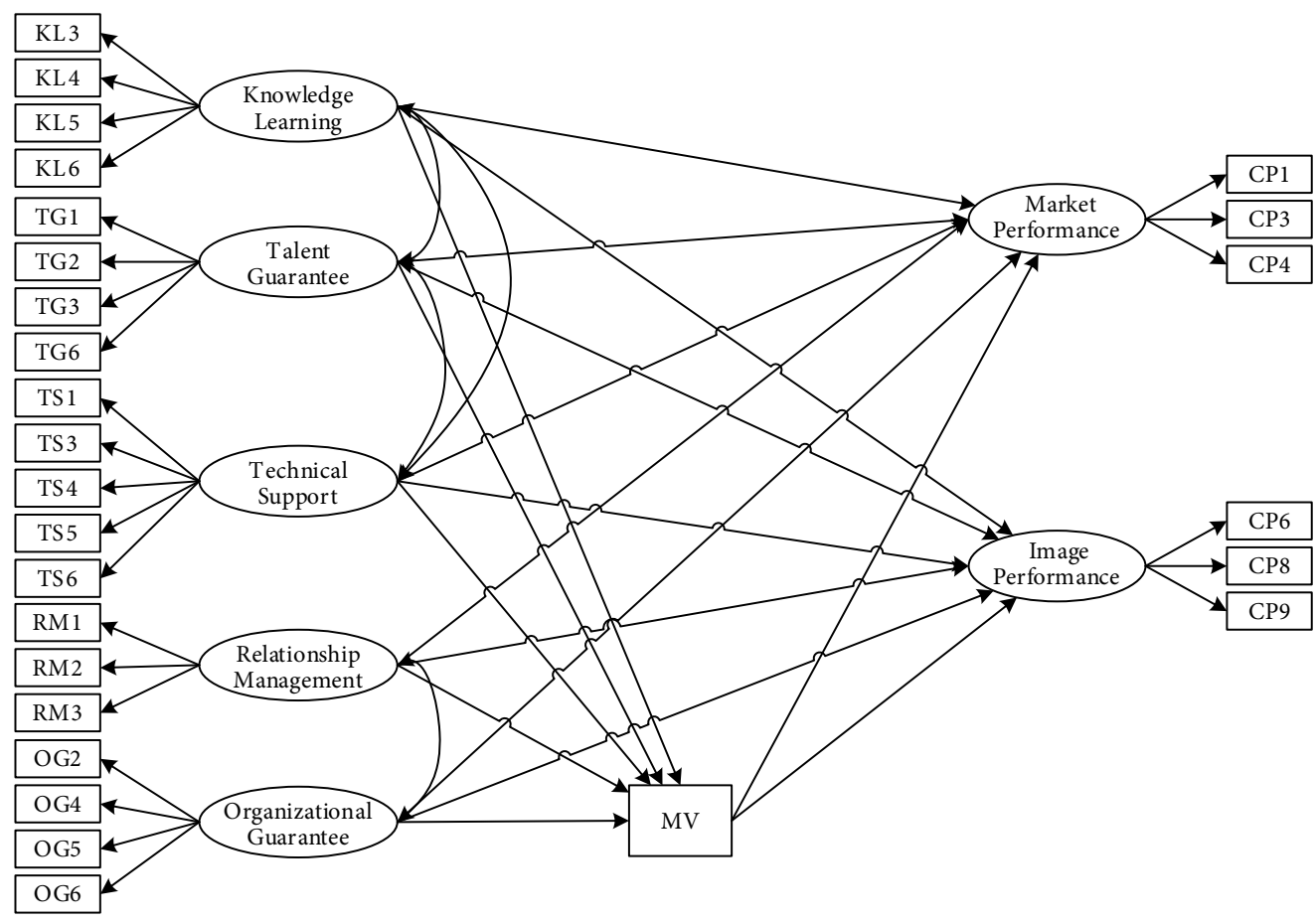

Figure 2. Baseline model of the ICS application capability to international contractors' competitiveness

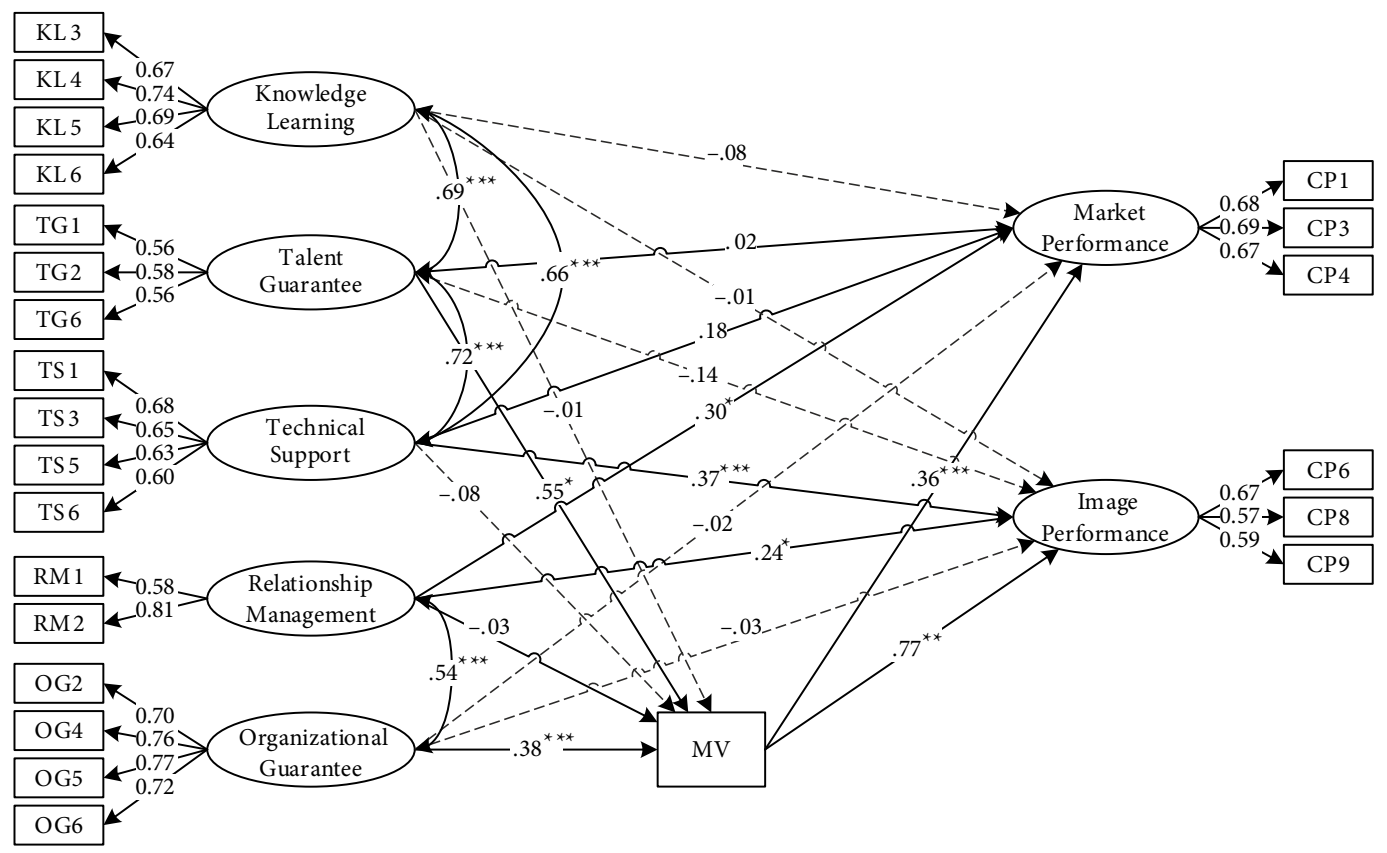

Notes: A solid line indicates a significant path (hypothesis supported); a dashed line indicates an insignificant path (hypothesis not supported). ${ }^{* *} \mathrm{p}<0.001 ;{ }^{* *} \mathrm{p}<0.01 ;{ }^{*} \mathrm{p}<0.05$.

Figure 3 . The final model with standardized regression coefficients 
Table 6. Indirect effects and 95\% confidence intervals for the final model

\begin{tabular}{|c|c|c|c|c|c|}
\hline \multirow{2}{*}{ Indirect effect path } & \multirow{2}{*}{ Estimated effect } & \multicolumn{2}{|c|}{ 95\%CI } & \multirow{2}{*}{ Interpretation } \\
\cline { 3 - 5 } & & Lower bounds & Upper bounds & & \\
\hline $\mathrm{KL} \rightarrow \mathrm{MV} \rightarrow \mathrm{CP}-\mathrm{M}$ & -0.005 & -1.475 & 0.213 & 0.754 & Not supported \\
\hline $\mathrm{KL} \rightarrow \mathrm{MV} \rightarrow \mathrm{CP}-\mathrm{I}$ & -0.011 & -1.273 & 0.352 & 0.910 & Not supported \\
\hline $\mathrm{TS} \rightarrow \mathrm{MV} \rightarrow \mathrm{CP}-\mathrm{M}$ & -0.029 & -2.330 & 0.322 & 0.526 & Not supported \\
\hline $\mathrm{TS} \rightarrow \mathrm{MV} \rightarrow \mathrm{CP}-\mathrm{I}$ & -0.065 & -2.194 & 0.273 & 0.694 & Not supported \\
\hline $\mathrm{TG} \rightarrow \mathrm{MV} \rightarrow \mathrm{CP}-\mathrm{M}$ & 0.188 & -0.231 & 4.610 & 0.079 & Not supported \\
\hline $\mathrm{TG} \rightarrow \mathrm{MV} \rightarrow \mathrm{CP}-\mathrm{I}$ & 0.421 & 0.041 & 6.200 & 0.039 & Supported \\
\hline $\mathrm{OG} \rightarrow \mathrm{MV} \rightarrow \mathrm{CP}-\mathrm{M}$ & 0.129 & -0.120 & 0.749 & 0.103 & Not supported \\
\hline $\mathrm{OG} \rightarrow \mathrm{MV} \rightarrow \mathrm{CP}-\mathrm{I}$ & 0.289 & 0.028 & 1.038 & 0.035 & Supported \\
\hline $\mathrm{RM} \rightarrow \mathrm{MV} \rightarrow \mathrm{CP}-\mathrm{M}$ & -0.010 & -0.285 & 0.070 & 0.608 & Not Supported \\
\hline $\mathrm{RM} \rightarrow \mathrm{MV} \rightarrow \mathrm{CP}-\mathrm{I}$ & -0.022 & -0.358 & 0.149 & 0.653 & Not supported \\
\hline
\end{tabular}

The indirect effects of the five latent variables on contractors' competitiveness were tested by the bootstrap estimation procedure in AMOS software. The results with $95 \%$ confidence intervals are shown in Table 6. For biascorrected and accelerated confidence, the indirect effect path can be verified if zero is between the lower bound and upper bound (Bollen \& Stine, 1990). Finally, combined with the final model, the key driving paths of the ICS application capability are determined $(\mathrm{RM} \rightarrow \mathrm{CP}$; $\mathrm{TS} \rightarrow \mathrm{CP}$; TG $\rightarrow \mathrm{MV} \rightarrow \mathrm{CP}$; OG $\rightarrow \mathrm{MV} \rightarrow \mathrm{CP}$ ). In addition, the estimated significant covariance and correlation relationships are shown in Figure 3.

\subsection{Path analysis and discussion}

\subsubsection{Main path analysis and discussion}

According to the results, two types of paths are identified:

- Path 1: Relationship management (RM) and technical support (TS) directly promote international contractors' competitiveness.

- Path 2: Talent guarantee (TG) and organizational support (OG) indirectly promote international contractors' competitiveness.

\section{$R M$ and TS have direct effects on international contractors' competitiveness}

Figure 3 shows that TS has the most significant direct effect on promoting the image performance of international contractors' competitiveness $(\beta=0.37)$, followed by RM $(\beta=0.24)$. For market performance, $\mathrm{RM}$ is regarded as the best driving factor $(\beta=0.30)$.

Technical support (TS) plays a positive role in improving image performance. Specifically, technical preparation, arrangement and preservation of the ICS can improve the technical leadership of contractors, which can result in a good image and enhance the image performance of international contractors in the international market. This conclusion is consistent with those of many scholars ( $\mathrm{Lu}$ et al., 2008; Pheng \& Hongbin, 2003).

Relationship management (RM) can directly and significantly promote both the market performance and im- age performance of international contractors. Effective communication with the owner and the supervisor about the ICS can not only effectively improve owner satisfaction and the quality of building products but also increase the market share and bid winning rate of contractors in the international market. This finding is consistent with the findings of past studies in this field (Coltman, 2007; Hooley et al., 2005; Paulraj et al., 2008).

\section{TG and $O G$ have indirect effects on international contractors' competitiveness}

TG and OG indirectly and significantly improve international contractors' competitiveness through a mediator variable (project performance). Specifically, according to the driving path coefficient, the indirect impact of TG ( $\beta=0.55)$ on international contractors' competitiveness is larger than that of $\mathrm{OG}(\beta=0.38)$.

Talent guarantee (TG) refers to the employment of ICS-related talent, the remarkable working capability of project managers and standard translators. As direct labor input of the project, excellent ICS talent can promote the realization of various project objectives and help contractors construct a good corporate image in the international market. It also provides the basis for the acquisition and implementation of subsequent projects. This finding corroborates the ideas of Ogunyomi and Bruning (2016), who suggested that human resource management can enhance the competitiveness of enterprises.

Organization guarantees (OGs) have a significant impact on project performance mainly by adjusting the organizational structure and management system. These adjustments can help project personnel better understand the adopted ICS and increase their familiarity with the local environment. In addition, cooperation with local contractors can further help the contractor localize and achieve project objectives regarding cost, quality and schedule. This finding supports the previous research of Mahadeen et al. (2016), which links the internal control and competitiveness of enterprises. 


\section{KL has no significant effect on contractors' competitiveness}

However, knowledge learning (KL) had neither a significant direct effect nor a significant indirect effect on contractors' competitiveness. That means knowledge learning (KL) does not directly affect contractors' competitiveness, nor does it affect the competitiveness through project performance. This may be because knowledge learning of ICS could be conductive to the development of technology and talents related, but it does not affect project performance or competitiveness directly. The project personnel can become more familiar with the ICS and implement projects effectively through sharing, training, arrangement and storage of ICS-related knowledge. Additionally, knowledge can also help contractors make better use of their technology and strengthen their understanding of the relevant ICS, which provides a good base for the realization of various project objectives and the enhancement of contractors' competitiveness. Interestingly, this result contradicts a study conducted by Prieto and Revilla (2006). The reason for this may be that this paper focuses on the knowledge learning capability of ICS, which is different from the definition and scope of learning capability in the study of Prieto and Revilla (2006). There is no doubt that comprehensive learning capability is indeed very import to the business performance. However, when the scope of learning capability gets smaller, the conclusion maybe a little different.

\subsubsection{Sub-path analysis and implications}

The main paths depict the relationships among the dimensions and competitiveness. To identify the critical impact paths, the sub-paths and implications are discussed below.

\section{Technical support sub-path}

According to the driving path coefficients of the TS-related items (TS1: 0.68; TS3: 0.65; TS5: 0.63; TS6: 0.60), advanced technology level (TS1) has the greatest impact on TS. The reason is that the technology required by the ICS cannot be improved in a short time but requires considerable time and money for R\&D investment.

Although the current technical level is not the main obstacle for large contractors to engage in overseas projects, the leading technical level of contractors can still effectively establish a reliable corporate image in the international market. First, project personnel should read the ICS carefully and figure out the technology referred in ICS before bidding in the non-domestic countries. After carefully studying the materials of the ICS, contractors should actively make technical preparations in advance. For materials that cannot be obtained in time in the non-domestic country and technology required by ICS is obviously difficult, contractors should develop alternative strategies, like purchasing building materials in neighboring countries and employing experienced local technicians. In addition, the management of overseas project technical data is also very important to improve the level of technical support. Technical data of overseas projects, including drawings, construction records, technical disclosure data, change records, etc., should be sorted by an e-commerce system in time and can be used as the basis for project implementation and provide valuable reference materials for similar projects in similar regions in the future.

Besides, due to the large consumption of the construction industry, standards for sustainable construction become increasingly important in the international market, and green construction technologies have gradually received more attention. It is no doubt that green technology can help to protect the environment, establish a good image for enterprises, and increase the contractors' competitiveness. However, there will be an extra cost if using green technology instead of traditional technology, which have an influence on project performance. Therefore, the financial impact of green building standards has been discussed by many scholars. Wijayasundara et al. (2016) established a model to evaluate the financial effect of manufacturing recycled aggregate concrete in lieu of normal concrete, and found that RMC plants having aggregate feeding mechanism with front-end loader (FEL) would be suitable, which will be conductive to improve the contractors' competitiveness from the perspective of project performance. Therefore, the relationships among international sustainable construction standards, financial impact, project performance and contractors' competitiveness should be further researched in the future.

\section{Relationship management sub-path}

From the perspective of relationship management, the impact of relationship with the supervisor (RM2: 0.814) is significantly greater than that with the owner (RM1: 0.576). In the process of overseas project implementation, all activities of project implementation require permission from the supervisor. Thus, a good cooperative relationship with all stakeholders, especially supervisors, is necessary for international contractors.

First, RM is the most direct driving factor to enhance contractors' competitiveness in the international market, especially for the promotion of market-oriented indicators, such as the bid winning rate and market share. In addition, it is very important to reach an agreement with the supervisor about the requirements of the ICS and to establish good communication and cooperation among stakeholders. This can directly improve the image performance in the region. Effective communication and active collaboration will contribute to successful completion of a project. In practice, there are some measures to strengthen the relationship management of stakeholders. First, the project management personnel should timely and clearly discuss the ICS requirements and tasks objectives with stakeholders at home and abroad. Besides, regular meeting and discussion among the team about the ICS related in the target projects is necessary. 


\section{Talent guarantee sub-path}

There is no significant difference among the three TGrelated items (TG1: 0.56; TG2: 0.58; TG6: 0.56), but the standard application capability (TG2) of the project manager is relatively important. It may be responsible for ensuring construction management in accordance with contract requirements. The understanding and skillful application of the ICS can effectively fulfill the requirements of contracts and corresponding standards and further promote project performance.

Excellent TG can not only promote the effective realization of various project objectives but also provide a talent foundation for TS. There are three suggestions for contractors in terms of talent guarantee. 1) Pay attention to the project manager's learning and understanding of the ICS, such as organizing the project manager overseas training and learning, participating in experience sharing and seminars, and hiring project managers with overseas engineering experience in the region. 2) Cultivate excellent translators of the ICS related. Specifically, a corresponding assessment mechanism for engineering professional ICSrelated knowledge should be established. 3) Establish a reward system. An excellent project manager with excellent ICS application capability should be rewarded with a promotion and bonus. In this way, managers with engineering experience can discover translation-related problems in time, which is of great significance for all project personnel to reasonably and efficiently apply the ICS.

\section{Organization guarantee sub-path}

The adaptation and adjustment of project organizational structure to the requirements of the ICS (OG5) has the greatest effect. One possible reason is that in the process of internal organizational project management, most activities are based on the project organization structure. Therefore, a suitable and reasonable project organization structure according to the ICS can provide internal guarantees for ICS applications.

According to the results of the path and sub-path analysis, OG can provide support for contractors to improve the application capability of the ICS and indirectly promote competitiveness in foreign markets. The key to improving the organization guarantee lies in 1) the adjustment of the project organization structure, such as setting up corresponding material and equipment management and purchasing groups overseas and setting up research departments of ICS; 2) the establishment of cultural awareness about the application capability of ICS, such as emphasizing the importance of ICS in routine work and do some activities and competitions about ICS learning and application. In this way, project personnel can realize that the application of the ICS plays an important role not only in project performance but also in improving the contractors' competitiveness from an organizational perspective.

Remarkably, although knowledge learning has no significant positive impact on the competitiveness of contrac- tors, as the basis of other capabilities, its effect cannot be neglected. ICS-related knowledge and application experience should be stored and disseminated through experience summaries, personnel sharing, etc. Written summary materials about international projects practice and ICS application can provide valuable resources for project personnel in the similar region with similar type of project. In addition, abundant theoretical learning opportunities of the ICS should be provided to project personnel, like training overseas, discussion with professor with ICS application experience and so on.

\section{Conclusions}

In this study, SEM was used to explore how ICS application capability affects international contractors' competitiveness in terms of five factors: knowledge learning $(\mathrm{KL})$, talent guarantee (TG), technical support (TS), relationship management (RM) and organization guarantee (OG). Contractor competitiveness was divided into market performance and image performance. In addition, project performance was applied as a mediator variable.

The results demonstrated two driving paths between ICS application capability and international contractors' competitiveness. TS directly promotes image performance, and RM has a significant direct positive impact on both market performance and image performance of international contractors' competitiveness. TG and OG indirectly promote international contractors' competitiveness by promoting project performance. However, KL has neither a direct driving effect nor an indirect positive effect on international contractors' competitiveness.

This study takes China as an example to identify dimensions of the ICS application capability of international contractors. In theory, this study has identified the driving paths of the ICS application capability on contractors' competitiveness, which can be a supplement for the research before. This study is also valuable in practice because it provides corresponding suggestions for contractors to improve international competitiveness by enhancing their ICS application capability. Specifically, targeted suggestions have been proposed and listed as: 1) advanced technical and material preparation according to the ICS in the region; 2) regular meetings and discussion about ICS application; 3) relevant project personnel overseas training about ICS application capability; 4) ICS application related organizational culture and research department establishment; 5) ICS related experience and knowledge sharing and summary.

However, due to the group size and geographical limitations, the scale of their group is limited to a certain extent. In addition, there is a lack of abundant previous theoretical research as a reference and basis, and the items of the ICS application capability established in this study need to be supplemented and improved. On the basis of this study, future research can further enrich and modify the items. Then, the sample size can be expanded to analyze the key application capacity dimensions of the ICS 
and examine the driving paths of international contractors' competitiveness. The indirect influence of the ICS application capability on international contractors' competitiveness can also be explored via different mediator variables, such as project management. In addition, the driving effect of the ICS application capacity on project performance can be studied.

\section{Acknowledgements}

The authors would also like to thank CHINA STATE CONSTRUCTION ENGRG. CORP. LTD., Beijing Construction Engineering Group CO., Ltd., Beijing Uni-Construction Group CO., Ltd., China National Nuclear CO. Ltd. and other international engineering managers for their research support, as well as the staff who cooperated in the research on overseas engineering projects.

\section{Funding}

This work was supported by the $<$ National Science Foundations of China> under Grant [No. 51778335] and the grant from the Institute for Guo Qiang, Tsinghua University.

\section{Author contributions}

All authors met the criteria for authorship of the Journal of Civil Engineering and Management. Xiaodong Li conceived the idea and designed the framework of the article. Chen Cheng collected the data. Dingyuan Ma and Chen Cheng were responsible for the construction of the model and data analysis. Dingyuan Ma wrote the draft of the article. Xiaodong Li was responsible for the review of the manuscript and provided suggestions.

\section{Disclosure statement}

All the authors have no conflict of interest.

\section{References}

Abuazoom, M. M. I., Hanafi, H. B., \& Ahmad, Z. Z. B. (2019). Do human resource management (HRM) practices improves project quality performance? Evidence from construction industry. Calitatea, 20, 81-86.

Adenfelt, M. (2010). Exploring the performance of transnational projects: shared knowledge, coordination and communication. International Journal of Project Management, 28(6), 529-538. https://doi.org/10.1016/j.ijproman.2009.10.004

Ansoff, H. I., \& McDonnell, E. J. (1988). The new corporate strategy. Wiley.

Anthony, R. N. (1988). The management control function. Harvard Business School Press.

Archibugi, D., \& Coco, A. (2004). A new indicator of technological capabilities for developed and developing countries (ArCo). World Development, 32(4), 629-654. https://doi.org/10.1016/j.worlddev.2003.10.008

Armstrong, M., \& Taylor, S. (2014). Armstrong's handbook of human resource management practice (13th ed.). Kogan Page.
Bassioni, H. A., Price, A. D. F., \& Hassan, T. M. (2005). Building a conceptual framework for measuring business performance in construction: an empirical evaluation. Construction Management and Economics, 23(5), 495-507.

https://doi.org/10.1080/0144619042000301401

Batarlienè, N., Čižiūnienė, K., Vaičiūtė, K., Šapalaitė, I., \& Jarašūnienè, A. (2017). The impact of human resource management on the competitiveness of transport companies. Procedia Engineering, 187, 110-116.

https://doi.org/10.1016/j.proeng.2017.04.356

Berssaneti, F. T., \& Carvalho, M. M. (2015). Identification of variables that impact project success in Brazilian companies. International Journal of Project Management, 33(3), 638-649. https://doi.org/10.1016/j.ijproman.2014.07.002

Bollen, K. A. (1989). Structural equations with latent variables. Wiley. https://doi.org/10.1002/9781118619179

Bollen, K. A., \& Stine, R. (1990). Direct and indirect effects: Classical and bootstrap estimates of variability. Sociological Methodology, 20(1), 115. https://doi.org/10.2307/271084

Chai, D. S., \& Dirani, K. (2018). The dimensions of the learning organization questionnaire (DLOQ). The Learning Organization, 25(5), 320-330. https://doi.org/10.1108/TLO-03-2016-0017

Chang, T., Deng, X., Hwang, B. G., \& Zhao, X. (2018). Political risk paths in international construction projects: Case study from Chinese construction enterprises. Advances in Civil Engineering, 6939828. https://doi.org/10.1155/2018/6939828

Cheung, S. O., \& Chow, P. T. (2011). Withdrawal in construction project dispute negotiation. Journal of Construction Engineering and Management, 137(12), 1071-1079.

https://doi.org/10.1061/(ASCE)CO.1943-7862.0000388

China National Institute of Standardization. (2002). GB/T 20000.1-2002 Guidelines for standardization - Part 1: standardization and related activities common vocabulary.

Coltman, T. (2007). Why build a customer relationship management capability? Journal of Strategic Information Systems, 16(3), 301-320. https://doi.org/10.1016/j.jsis.2007.05.001

Committee of Sponsoring Organizations of the Treadway Commission. (2019). COSO internal control - Integrated framework: An implementation guide for the healthcare provider industry. Crowe.

David, L. S. (2003). Starting at the beginning: An introduction to coefficient alpha and internal consistency. Journal of Personality Assessment, 80(1), 99-103.

https://doi.org/10.1207/S15327752JPA8001_18

Deng, F., Liu, G., \& Jin, Z. (2013). Factors formulating the competitiveness of the Chinese construction industry: Empirical investigation. Journal of Management in Engineering, 29(4), 435-445.

https://doi.org/10.1061/(ASCE)ME.1943-5479.0000161

Durdyev, S., Ismail, S., \& Kandymov, N. (2018). Structural equation model of the factors affecting construction labor productivity. Journal of Construction Engineering and Management, 144(4), 04018007. https://doi.org/10.1061/(ASCE)CO.1943-7862.0001452

Elyamany, A. H. M. (2010). Developing a rational approach for contractor selection based on history of construction quality and long -term performance (Publication No. 743815067) [Doctoral dissertation]. Proquest, Umi Dissertation Publishing.

Engineering News-Record (ENR). (2019). The top 250 international contractors list. https://www.enr.com/toplists/2019Top-250-International-Contractors-1 
Erdogan, B., Abbott, C., \& Aouad, G. (2010). Construction in year 2030: developing an information technology vision. Philosophical Transactions of the Royal Society A - Mathematical Physical and Engineering Sciences, 368, 3551-3565. https://doi.org/10.1098/rsta.2010.0076

Eybpoosh, M., Dikmen, I., \& Birgonul, M. T. (2011). Identification of risk paths in international construction projects using structural equation modeling. Journal of Construction Engineering and Management, 137(12), 1164-1175. https://doi.org/10.1061/(ASCE)CO.1943-7862.0000382

Ferreira, A., \& Otley, D. (2009). The design and use of performance management systems: An extended framework for analysis. Management Accounting Research, 20(4), 263-282. https://doi.org/10.1016/j.mar.2009.07.003

Floyd, F. J., \& Widaman, K. F. (1995). Factor analysis in the development and refinement of clinical assessment instruments. Psychological Assessment, 7(3), 286-199.

https://doi.org/10.1037/1040-3590.7.3.286

Foster-Fishman, P. G., Berkowitz, S. L., Lounsbury, D. W., Jacobson, S., \& Allen, N. A. (2001). Building collaborative capacity in community coalitions: A review and integrative framework. American Journal of Community Psychology, 29(2), 241-261. https://doi.org/10.1023/a:1010378613583

Galetić, L., Načinović, I., \& Klindžić, M. (2012). Transforming the organizational structure and culture to sustain long-term competitiveness. In Proceedings of the 6th International Conference An Enterprise Odyssey: Corporate governance and public policy - path to sustainable future (pp. 911-924). Zagreb, Croatia.

Gao, G. D. (2010). Discussion about the application of Chinese quota in large-scale international engineering bidding. Construction Economy, 4, 37-38 (in Chinese).

Gefen, D. (2000). E-commerce: the role of familiarity and trust. Omega, 28(6), 725-737.

https://doi.org/10.1016/s0305-0483(00)00021-9

Goh, S., \& Richards, G. (1997). Benchmarking the learning capability of organizations. European Management Journal, 15(5), 575-583. https://doi.org/10.1016/s0263-2373(97)00036-4

Gunduz, M., Birgonul, M. T., \& Ozdemir, M. (2017). Fuzzy structural equation model to assess construction site safety performance. Journal of Construction Engineering and Management, 143(4), 04016112.

https://doi.org/10.1061/(ASCE)CO.1943-7862.0001259

Gunhan, S., \& Arditi, D. (2005). Factors affecting international construction. Journal of Construction Engineering and Management, 131(3), 273-282.

https://doi.org/10.23883/IJRTER.2017.3415.CEGVN

Gurmu, A. T. (2020). Fuzzy synthetic evaluation of human resource management practices influencing construction labour productivity. International Journal of Productivity and Performance Management.

https://doi.org/10.1108/IJPPM-04-2019-0198

Hair, Jr., J. F., Black, W. C., Babin, B. J., \& Anderson, R. E. (2009). Multivariate data analysis (7th ed.) Pearson.

Hamel, G., \& Prahalad, C. K. (1990). The core competence of the corporation. Harvard Business Review, 68(3), 79-91.

Han, S. H., \& Diekmann, J. E. (2001). Approaches for making riskbased go/no-go decision for international projects. Journal of Construction Engineering and Management, 127(4), 300-308. https://doi.org/10.1061/(ASCE)0733-9364(2001)127:4(300)

Han, S. H., Kim, D. Y., Jang, H. S., \& Choi, S. (2010). Strategies for contractors to sustain growth in the global construction market. Habitat International, 34(1), 1-10. https://doi.org/10.1016/j.habitatint.2009.04.003
Han, J., Park, H., Ock, J., \& Jang, H. (2015). An international competitiveness evaluation model in the global construction industry. KSCE Journal of Civil Engineering, 19(3), 465-477. https://doi.org/10.1007/s12205-012-0486-Z

Hasan, A., Hassan, R., Ali, E. R. A. E., Ali, E. M. T. E., Abduh, M., \& Noordin, N. H. (2019). A proposed human resource management model for zakat institutions in Malaysia. ISRA International Journal of Islamic Finance, 11(1), 98-109. https://doi.org/10.1108/ijif-10-2017-0036

Hatush, Z., \& Skitmore, M. (1997). Criteria for contractor selection. Construction Management and Economics, 15(1), 19-38. https://doi.org/10.1080/014461997373088

Hooley, G. J., Greenley, G. E., Cadogan, J. W., \& Fahy, J. (2005). The performance impact of marketing resources. Journal of Business Research, 58(1), 18-27. https://doi.org/10.1016/S0148-2963(03)00109-7

Hsu, Y.-H., \& Fang, W. (2009). Intellectual capital and new product development performance: The mediating role of organizational learning capability. Technological Forecasting and Social Change, 76(5), 664-677.

https://doi.org/10.1016/j.techfore.2008.03.012

Iliescu, M., \& Ciocan, R. (2017). Modern technologies innovation in use for quality control on construction site. Procedia Engineering, 181, 999-1004.

https://doi.org/10.1016/j.proeng.2017.02.499

Javernick-Will, A. N., \& Scott, W. R. (2010). Who needs to know what? Institutional knowledge and global projects. Journal of Construction Engineering and Management, 136(5), 546-557. https://doi.org/10.1017/cbo9780511792533.009

Jerez-Gómez, P., Cespedes-Lorente, J., \& Valle-Cabrera, R. (2005). Organizational learning capability: a proposal of measurement. Journal of Business Research, 58(6), 715-725. https://doi.org/10.1016/j.jbusres.2003.11.002

Komurlu, R., Arditi, D., \& Gurgun, A. P. (2015). Energy and atmosphere standards for sustainable design and construction in different countries. Energy and Buildings, 90, 156-165. https://doi.org/10.1016/j.enbuild.2015.01.010

Kotter, J. P., \& Heskett, J. L. (1992). Corporate culture and performance. The Free Press.

Khandekar, A., \& Sharma, A. (2005). Managing human resource capabilities for sustainable competitive advantage: An empirical analysis from Indian global organisations. Education + Training, 47(8/9), 628-639. https://doi.org/10.1108/00400910510633161

Kwon, D. K., \& Kareem, A. (2013). Comparative study of major international wind codes and standards for wind effects on tall buildings. Engineering Structures, 51, 23-35. https://doi.org/10.1016/j.engstruct.2013.01.008

Lei, Z., Tang, W., Duffield, C., Zhang, L., \& Hui, F. K. P. (2017). The impact of technical standards on international project performance: Chinese contractors' experience. International Journal of Project Management, 35(8), 1597-1607. https://doi.org/10.1016/j.ijproman.2017.09.002

Li, X. D., Guan, K., \& Lai, X. (2004). Comprehensive evalaution and simulation analysis of interntional competitiveness of top contractors. Journal of Harbin Institute of Technology, 10, 1354-1357 (in Chinese).

Li, H. R., Chen, H., Li, Q. M., Chen, C., \& Li, Z. (2017). Research on the development strategy of China's international engineering contractors - Based on the performance data of the world's largest 250 international engineering contractors from 2000 to 2015. Journal of International Economic Cooperation, 4, 27-33 (in Chinese). 
Lindkvist, L. (2004). Governing project-based firms: Promoting market-like processes within hierarchies. Journal of Management and Governance, 8(1), 3-25.

https://doi.org/10.1023/B:MAGO.0000015392.75507.ad

Liu, J., Zhao, X., \& Yan, P. (2016). Risk paths in international construction projects: Case study from Chinese contractors. Journal of Construction Engineering and Management, 142(6), 05016002 .

https://doi.org/10.1061/(ASCE)CO.1943-7862.0001116

Lu, W., Shen, L., \& Yam, M. (2008). Critical success factors for competitiveness of contractors: China study. Journal of Construction Engineering and Management, 134(12), 972-982. https://doi.org/10.1061/(ASCE)0733-9364(2008)134:12(972)

Lueg, R., \& Radlach, R. (2016). Managing sustainable development with management control systems: A literature review. European Management Journal, 34(2), 158-171.

https://doi.org/10.1016/j.emj.2015.11.005

Mahadeen, B., Al-Dmour, R. H., Obeidat, B. Y., \& Tarhini, A. (2016). Examining the effect of the organization's internal control system on organizational effectiveness: A Jordanian empirical study. International Journal of Business Administration, 7(6), 22-41. https://doi.org/10.5430/ijba.v7n6p22

Marsh, H. W., \& Hau, K. T. (1996). Assessing goodness of fit: Is parsimony always desirable? Journal of Experimental Education, 64(4), 364-390.

https://doi.org/10.1080/00220973.1996.10806604

Marsick, V. J. (2013). The dimensions of a learning organization questionnaire (DLOQ) introduction to the special issue examining DLOQ use over a decade. Advances in Developing Human Resources, 15(2), 127-132.

https://doi.org/10.1177/1523422313475984

Marsick, V. J., \& Watkins, K. E. (2003). Demonstrating the value of an organization's learning culture: The dimensions of the learning organization questionnaire. Advances in Developing Human Resources, 5(2), 132-151.

https://doi.org/10.1177/1523422303005002002

Matlay, H., Khandekar, A., \& Sharma, A. (2005). Organizational learning in Indian organizations: a strategic HRM perspective. Journal of Small Business \& Enterprise Development, 12(2), 211-226. https://doi.org/10.1108/14626000510594610

McDonald, \& Roderick, P. (1999). Test theory: a unified treatment. Lawrence Erlbaum Associates.

Meng, X. (2012). The effect of relationship management on project performance in construction. International Journal of Project Management, 30(2), 188-198.

https://doi.org/10.1016/j.ijproman.2011.04.002

Merna, A., \& Smith, N. J. (1990). Bid evaluation for UK public sector construction contracts. Proceedings of the Institution of Civil Engineers, 88(1), 91-105.

https://doi.org/10.1680/iicep.1990.4529

Mohamad, M. R., \& Zin, N. M. (2019). Knowledge management and the competitiveness of small construction firms. Competitiveness Review: An International Business Journal, 29(5), 534-550. https://doi.org/10.1108/cr-03-2018-0027

Moon, T. (2010). Organizational cultural intelligence: Dynamic capability perspective. Group \& Organization Management, 35(4), 456-493. https://doi.org/10.1177/1059601110378295

Ng, P. K., Goh, G. G. G., \& Eze, U. C. (2011). The importance of $\mathrm{CAD}$ and knowledge management in concurrent engineering project performance. Journal of Information \& Knowledge Management, 10(4), 365-378.

https://doi.org/10.1142/s0219649211003061

Nicolaou, A. I., \& Masoner, M. M. (2013). Sample size requirements in structural equation models under standard condi- tions. International Journal of Accounting Information Systems, 14(4), 256-274. https://doi.org/10.1016/j.accinf.2013.11.001

Norris, G., \& O'Dwyer, B. (2004). Motivating socially responsive decision making: the operation of management controls in a socially responsive organisation. The British Accounting Review, 36(2), 173-196.

https://doi.org/10.1016/j.bar.2003.11.004

Ogunyomi, P., \& Bruning, N. S. (2016). Human resource management and organizational performance of small and medium enterprises (SMEs) in Nigeria. The International Journal of Human Resource Management, 27(6), 612-634.

https://doi.org/10.1080/09585192.2015.1033640

Ogwueleka, A. (2011). The critical success factors influencing project performance in Nigeria. International Journal of Management Science and Engineering Management, 6(5), 343-349. https://doi.org/10.1080/17509653.2011.10671182

Ozorhon, B., Arditi, D., Dikmen, I., \& Birgonul, M. T. (2008). Effect of partner fit in international construction joint ventures. Journal of Management in Engineering, 24(1), 12-20. https://doi.org/10.1061/(ASCE)0742-597X(2008)24:1(12)

Paulraj, A., Lado, A. A., \& Chen, I. J. (2008). Inter-organizational communication as a relational competency: Antecedents and performance outcomes in collaborative buyer-supplier relationships. Journal of Operations Management, 26(1), 45-64. https://doi.org/10.1016/j.jom.2007.04.001

Pheng, L. S., \& Hongbin, J. (2003). Internationalization of Chinese construction enterprises. Journal of Construction Engineering and Management, 129(6), 589-598. https://doi.org/10.1061/(ASCE)0733-9364(2003)129:6(589)

Porter, M. (1990). The comparative advantage of nations. The Free Press. https://doi.org/10.1007/978-1-349-11336-1

Price, B., Comrey, A. L., \& Lee, H. B. (1993). A first course in factor analysis. Technometrics, 35(4), 453.

https://doi.org/10.1080/00401706.1993.10485363

Prieto, I. M., \& Revilla, E. (2006). Assessing the impact of learning capability on business performance: Empirical evidence from Spain. Management Learning, 37(4), 499-522. https://doi.org/10.1177/1350507606070222

Rose, K. H. (Ed.) (2013). A guide to the project management body of knowledge (PMBOK ${ }^{\oplus}$ Guide) (5th ed.). Wiley. https://doi.org/10.1002/pmj.21345

Russell, J. S., \& Skibniewski, M. J. (1988). Decision criteria in contractor prequalification. Journal of Management in Engineering, 4(2), 148-164.

https://doi.org/10.1061/(ASCE)9742-597X(1988)4:2(148)

Shahhosseini, V., \& Sebt, M. H. (2011). Competency-based selection and assignment of human resources to construction projects. Scientia Iranica, 18(2), 163-180.

https://doi.org/10.1016/j.scient.2011.03.026

Sharif, M. N. (1997). Technology strategy in developing countries: evolving from comparative to competitive advantage. International Journal of Technology Management, 14(2-4), 309-343. https://doi.org/10.1504/ijtm.1997.001729

Tan, Y., Ochoa, J., Langston, C., \& Shen, L. (2015). An empirical study on the relationship between sustainability performance and business competitiveness of international construction contractors. Journal of Cleaner Production, 93, 273-278. https://doi.org/10.1016/j.jclepro.2015.01.034

Tan, Y., Xue, B., \& Cheung, Y. (2017). Relationships between main contractors and subcontractors and their impacts on main contractor competitiveness: An empirical study in Hong Kong. Journal of Construction Engineering and Management, 143(7), 05017007. https://doi.org/10.1061/(ASCE)CO.1943-7862.0001311 
Turk, A. (2006). ISO 9000 in construction: An examination of its application in Turkey. Building and Environment, 41(4), 501-511. https://doi.org/10.1016/j.buildenv.2005.02.013

Valero, E., \& Adán, A. (2016). Integration of RFID with other technologies in construction. Measurement, 94, 614-620. https://doi.org/10.1016/j.measurement.2016.08.037

van Popering-Verkerk, J., \& van Buuren, A. (2017). Developing collaborative capacity in pilot projects: Lessons from three Dutch flood risk management experiments. Journal of Cleaner Production, 169, 225-233.

https://doi.org/10.1016/j.jclepro.2017.04.141

Wijayasundara, M., Mendis, P., Zhang, L., Sofi, M. (2016). Financial assessment of manufacturing recycled aggregate concrete in ready-mix concrete plants. Resources, Conservation \& Recycling, 109, 187-201.

https://doi.org/10.1016/j.resconrec.2016.02.007

Wright, P. M., \& McMahan, G. C. (1992). Theoretical perspectives for strategic human resource management. Journal of Management, 18(2), 295-320. https://doi.org/10.1177/014920639201800205

Wu, J.-N., \& Zhong, W.-J. (2009). Application capability of ebusiness and enterprise competitiveness: A case study of the iron and steel industry in China. Technology in Society, 31(3), 198-206. https://doi.org/10.1016/j.techsoc.2009.06.004

Wu, J.-N., Zhong, W.-J., \& Mei, S.-E. (2011). Application capability of e-business, e-business success, and organizational performance: Empirical evidence from China. Technological Forecasting and Social Change, 78(8), 1412-1425. https://doi.org/10.1016/j.techfore.2011.03.023

Yan, J. F. (2012). Research on problems of engineering construction standards in the international engineering. Construction Economy, 7, 57-60 (in Chinese).

Yan, S. (2017). Strategic analysis of international competitiveness for construction firms in China. In 2017 World Conference on Management Science and Human Social Development (MSHSD 2017). https://doi.org/10.2991/mshsd-17.2018.1

Yao, Y. B., Chen, Z. X., \& Jia, Y. (2013). Tourist trustworthiness of destination: Dimension and its consequence. Tourism Tribune, 28(4), 48-56 (in Chinese).

Yates, J. K., \& Aniftos, S. C. (1996). International standards: the US construction industry's competitiveness. Cost Engineering, 38(7), 32.

Yates, J. K., \& Aniftos, S. (1997). International standards and construction. Journal of Construction Engineering and Management, 123(2), 127-137.

https://doi.org/10.1061/(ASCE)0733-9364(1997)123:2(127)

Yu, A. T., Shen, Q., Kelly, J., \& Hunter, K. (2006). Investigation of critical success factors in construction project briefing by way of content analysis. Journal of Construction Engineering and Management, 132(11), 1178-1186. https://doi.org/10.1061/(ASCE)0733-9364(2006)132:11(1178)

Zahra, S. A., Neubaum, D. O., \& Larrañeta, B. (2007). Knowledge sharing and technological capabilities: The moderating role of family involvement. Journal of Business research, 60(10), 1070-1079. https://doi.org/10.1016/j.jbusres.2006.12.014

Zhao, Z., Shen, L., \& Zuo, J. (2009). Performance and strategy of Chinese contractors in the international market. Journal of Construction Engineering and Management, 135(2), 108-118. https://doi.org/10.1061/(ASCE)0733-9364(2009)135:2(108)

Zou, W., Kumaraswamy, M., Chung, J., \& Wong, J. (2014). Identifying the critical success factors for relationship management in PPP projects. International Journal of Project Management, 32(2), 265-274.

https://doi.org/10.1016/j.ijproman.2013.05.004 